\title{
The Olivocerebellar Projection Mediates Ibogaine-Induced Degeneration of Purkinje Cells: A Model of Indirect, Trans-Synaptic Excitotoxicity
}

\author{
Elizabeth O'Hearn and Mark E. Molliver \\ Departments of Neuroscience and Neurology, The Johns Hopkins University School of Medicine, \\ Baltimore, Maryland 21205
}

Ibogaine, an indole alkaloid that causes hallucinations, tremor, and ataxia, produces cerebellar neurotoxicity in rats, manifested by degeneration of Purkinje cells aligned in narrow parasagittal bands that are coextensive with activated glial cells. Harmaline, a closely related alkaloid that excites inferior olivary neurons, causes the same pattern of Purkinje cell degeneration, providing a clue to the mechanism of toxicity. We have proposed that ibogaine, like harmaline, excites neurons in the inferior olive, leading to sustained release of glutamate at climbing fiber synapses on Purkinje cells. The objective of this study was to test the hypothesis that increased climbing fiber activity induced by ibogaine mediates excitotoxic Purkinje cell degeneration. The inferior olive was pharmacologically ablated in rats by a neurotoxic drug regimen using 3-acetylpyridine, and cerebellar damage attributed to subsequent administration of ibogaine was analyzed using immunocytochem- ical markers for neurons and glial cells. The results show that ibogaine administered after inferior olive ablation produced little or no Purkinje cell degeneration or glial activation. That a lesion of the inferior olive almost completely prevents the neurotoxicity demonstrates that ibogaine is not directly toxic to Purkinje cells, but that the toxicity is indirect and dependent on integrity of the olivocerebellar projection. We postulate that ibogaine-induced activation of inferior olivary neurons leads to release of glutamate simultaneously at hundreds of climbing fiber terminals distributed widely over the surface of each Purkinje cell. The unique circuitry of the olivocerebellar projection provides this system with maximum synaptic security, a feature that confers on Purkinje cells a high degree of vulnerability to excitotoxic injury.

Key words: ibogaine; harmaline; Purkinje cell; cerebellum; excitotoxicity; climbing fiber; inferior olivary nucleus; microglia
Ibogaine is a psychoactive five-ringed indole alkaloid extracted from the root of an African plant, Tabernanthe iboga (Dhahir, 1971). This drug is a CNS stimulant with multiple pharmacological effects that include production of hallucinations, tremor, and ataxia (Schneider and Sigg, 1956; Popik et al., 1995). Based on anecdotal reports that ibogaine may suppress craving associated with drug addiction and may reduce signs of drug withdrawal in humans (Lotsof, 1985, 1986, 1995; Sheppard, 1994), this compound has been considered for clinical use in the treatment of drug addiction. However, based on a study to detect neurotoxic effects of ibogaine, this laboratory reported that treatment with either ibogaine or the related drug harmaline can lead to neuronal injury in the cerebellum of rats. The cytotoxic effects are located predominantly in the vermis of the cerebellum and manifested by neuronal degeneration accompanied by marked gliosis (O'Hearn and Molliver, 1993; O'Hearn et al., 1993). The neurotoxicity induced by ibogaine is selective for Purkinje cells and is characterized by a distinctive spatial pattern, such that degenerating Purkinje cells are aligned in narrow longitudinal bands within the vermis and, less frequently, in the paravermis or hemispheres. Activated microglia and astrocytes form sagittally oriented radial stripes that are in register with the longitudinal bands in which Purkinje cells have degenerated (Fig. 1).

\footnotetext{
Received April 30, 1997; revised Sept. 3, 1997; accepted Sept. 8, 1997.

This work was supported by United States Public Health Service Grants DA 08692, DA 00225, and NO1DA-3-7301.

Address all correspondence to Dr. Elizabeth O'Hearn, Department of Neuroscience, PCTB 1032, Johns Hopkins University School of Medicine, 725 North Wolfe Street, Baltimore, MD 21205.

Copyright (C) 1997 Society for Neuroscience $\quad 0270-6474 / 97 / 178828-14 \$ 05.00 / 0$
}

Administration of ibogaine produces abnormal motor behavior that includes a high frequency tremor associated with marked ataxia in mice (Zetler et al., 1972; Singbartl et al., 1973) and in rats (Glick et al., 1992; O'Hearn and Molliver, 1993). The behavioral effects induced by ibogaine are indistinguishable from effects produced by two related indole alkaloids, harmaline and ibogaline (Singbartl et al., 1973; Zetler et al., 1974). The latter two drugs have powerful CNS excitatory effects manifested by a markedly increased firing rate of neurons within the inferior olivary nucleus (De Montigny and Lamarre, 1973, 1974; Llinás and Volkind, 1973). Based on the pharmacological similarities among these three drugs, we propose that ibogaine, like harmaline and ibogaline, is likely to increase the excitability and firing of neurons in the inferior olive. The mechanisms by which ibogaine and related $\beta$-carboline compounds produce increased inferior olive activity are not fully characterized, and other sites at which ibogaine may act in the CNS have not yet been clearly identified. Based on the evidence available, we have postulated that the degeneration of Purkinje cells produced by both ibogaine and harmaline results from excitotoxic injury (O'Hearn and Molliver, 1993; O'Hearn et al., 1995). In accord with the excitotoxic hypothesis (Olney, 1978; Choi, 1988), these drugs should produce a sustained increase in neuronal firing in the inferior olive, leading to release of excessive glutamate from climbing fiber terminals that synapse on longitudinal arrays of Purkinje cells. The repetitive release of an excitatory neurotransmitter, sustained over many hours, is likely to produce irreversible, excitotoxic damage to Purkinje cells, followed by their degeneration.

The purpose of the present study is to test the hypothesis that ibogaine-induced degeneration of Purkinje cells results from ex- 
cessive and prolonged activation of the olivocerebellar projection. To evaluate the role of climbing fibers in mediating neuronal degeneration attributed to ibogaine, the inferior olivary nucleus was chemically ablated in rats by means of a systemic, neurotoxic drug regimen that has been shown to produce relatively selective degeneration of neurons in the inferior olive (Llinás et al., 1975; Anderson and Flumerfelt, 1980; Balaban, 1985). Six days after sustaining olivary lesions, rats were injected with ibogaine and allowed to survive for an additional week. The animals were killed 1 week after ibogaine treatment, and brain sections were obtained to analyze the degree of Purkinje cell degeneration and to verify inferior olive ablation. The extent of Purkinje cell degeneration produced by ibogaine after ablation of the inferior olive was compared with ibogaine-induced degeneration in normal rats with intact inferior olives. If Purkinje cell degeneration induced by ibogaine is mediated via the olivocerebellar projection, then ablation of the inferior olive before ibogaine administration would be expected to prevent the neuronal loss.

\section{MATERIALS AND METHODS}

Subjects. Male Sprague Dawley rats $(n=40,175-220$ gm; Harlan Sprague Dawley, Indianapolis, IN) were housed individually on the day before and the day after drug treatments, after which they were housed in groups of three or four. No solid food was available from the night before and up until drug administration, after which they had free access to food (Prolab RMH 1000; PMI Feeds, St. Louis, MO) and water. Cages were located in a temperature-regulated room $\left(70^{\circ} \mathrm{F}\right)$ with a $12 \mathrm{hr}$ light/dark cycle.

All solutions were administered by intraperitoneal injection. Drug doses are expressed as weights of the salt (ibogaine- $\mathrm{HCl}$; obtained from the National Institute on Drug Abuse) or of the free base 3acetylpyridine (3-AP), harmaline, or nicotinamide (Sigma, St. Louis, MO) per kilogram of rat body weight. Solution concentrations were as follows: 3-AP, $25 \mathrm{mg} / \mathrm{ml}$ saline; harmaline, $7 \mathrm{mg} / \mathrm{ml}$ saline; nicotinamide, $60 \mathrm{mg} / \mathrm{ml}$ saline; and ibogaine- $\mathrm{HCl}, 10 \mathrm{mg} / \mathrm{ml}$ distilled water. Control rats received one injection of normal saline in a volume equal to that of ibogaine administered to treated rats.

Treatment paradigms. Animals were assigned to four treatment groups: (1) group A, the 3-AP regimen: 3-AP $(68-70 \mathrm{mg} / \mathrm{kg})$ followed by harmaline $(15-20 \mathrm{mg} / \mathrm{kg}) 2 \mathrm{hr}$ later and by nicotinamide $(300 \mathrm{mg} / \mathrm{kg})$ an additional $2.5 \mathrm{hr}$ later ( $4.5 \mathrm{hr}$ after 3 -AP); after $6 \mathrm{~d}$ these rats were given ibogaine $(100 \mathrm{mg} / \mathrm{kg})$ and observed for 1 week before killing and neuroanatomic examination $(n=17)$; (2) group $\mathrm{B}, 3-\mathrm{AP}$, harmaline, and nicotinamide as in group $\mathrm{A}$, followed $6 \mathrm{~d}$ later by saline $(n=8)$; (3) group $\mathrm{C}$, ibogaine alone $(100 \mathrm{mg} / \mathrm{kg})$ on the same day it was administered to animals in group A $(n=6)$; and (4) group $\mathrm{D}$, saline $(n=6)$ or no treatment $(n=3)$ on the same day ibogaine was given to animals in groups $\mathrm{A}$ and $\mathrm{C}$.

This study was conducted in four sequential trials, each of which included animals from the four treatment groups. In proceeding through the four trials, the dose of 3 -AP was varied $(68-70 \mathrm{mg} / \mathrm{kg})$, as was harmaline $(15-20 \mathrm{mg} / \mathrm{kg}$ ) to maximize selective neuronal loss in the inferior olive. Harmaline was administered $2 \mathrm{hr}$ after 3-AP (instead of 3 hr, as used by Llinás et al., 1975) to increase the selectivity of this regimen for inferior olivary neurons. Based on reports that $1-6 \mathrm{~d}$ are required for ablation of neurons of the inferior olive after the 3-AP regimen (Desclin and Escubi, 1974; Llinás et al., 1975; Sotelo et al., 1975), ibogaine was given $6 \mathrm{~d}$ after the 3-AP regimen.

Immunocytochemical evaluation. One week after ibogaine (or saline) treatment, animals were deeply anesthetized with pentobarbital $(80$ $\mathrm{mg} / \mathrm{kg}$, i.p.) and perfused through the left ventricle with cold $4 \%$ paraformaldehyde in $0.15 \mathrm{M}$ phosphate buffer, $\mathrm{pH}$ 7.4. Brains were post-fixed in the same solution for 4-6 hr and cryoprotected in $10 \%$ DMSO in PBS. The cerebellum was sectioned at $40 \mu \mathrm{m}$ on a freezing sliding microtome. Every fourth section was collected and prepared for immunohistochemical examination or Nissl stain.

Immunohistochemical staining was performed on freely floating sections. Primary antibodies included neuronal markers for calbindin (1: 8000, R17; a gift from P. Emson, Cambridge University) and calciumand calmodulin-dependent protein kinase II (Cam-kin II) (1:1000; Boehringer Mannheim, Indianapolis, IN). Microglial markers used were
MRC OX42 (1:1000; Serotec, Oxford, UK), an antibody to the complement receptor 3, and MRC OX6 (1:3000; Serotec), an antibody to the major histocompatibility complex II (MHC II) antigen. Astrocytes were labeled with an antibody to glial fibrillary acidic protein (GFAP) (1: 15,000; Dako, Via Real, CA). Primary antibody incubation solutions contained $0.2 \%$ Triton X-100 and $2 \%$ normal goat or horse serum (Vector Laboratories, Burlingame, CA) in PBS or Blotto. To reduce background staining for Cam-kin II, OX42, and OX6, sections were immersed in solutions containing $0.2 \%$ Triton X-100, $2 \%$ normal horse serum, and Blotto for $60 \mathrm{~min}$ before incubation in gently agitated primary antibody solutions for $48-72 \mathrm{hr}$ at $4^{\circ} \mathrm{F}$. Primary antibodies were visualized using Vectastain ABC Elite reagents (Vector) and the chromagen 3,3'-diaminobenzidine (Sigma). Sections were examined with a Leitz $\mathrm{DMRB} / \mathrm{E}$ microscope equipped for bright field and differential interference contrast.

\section{RESULTS}

\section{Motor effects of drug treatment}

\section{Ibogaine alone}

After receiving ibogaine $(100 \mathrm{mg} / \mathrm{kg}$, i.p., once), rats displayed a predictable sequence of behavioral signs. Within $3 \mathrm{~min}$, they developed a high frequency tremor of the trunk, head, and limbs, followed by marked ataxia manifested by a wobbling gait and frequent falls. During the initial 5 min many rats exhibited myoclonic jerks of the limbs, followed by brief episodes $(5-10 \mathrm{sec})$ that included extension of the head, rapid patting movements of forelimbs with extension of digits, and repetitive facial movements. These seizure-like episodes started and stopped abruptly and were typically followed by immobility for several seconds, after which ataxia returned. Not uncommonly, rats were projected off the floor by extensor limb movements during the first 5 min after ibogaine treatment.

The initial episode of ibogaine-induced tremor, ataxia, and myoclonus was followed by a period of marked hypotonia. At 8-10 min after receiving ibogaine, rats lay prone with their heads on the floor and with limp, motionless limbs, yet they remained awake with eyes open. The only visible spontaneous movements were those of abdominal and thoracic muscles related to respiration. Although they were extremely hypotonic, the rats responded to noxious stimuli; a foot pinch elicited withdrawal of limbs. No tremor was present during the hypotonic stage, which lasted for $15 \mathrm{~min}$ and was followed by gradual return of truncal tone and spontaneous limb movements. Recovery of muscle tone and upright posture at 30-60 min after treatment were accompanied by recurrence of tremor and ataxia. The latter signs diminished over $18 \mathrm{hr}$ and, at $24 \mathrm{hr}$ after treatment, the behavior of treated rats could not be distinguished from that of controls. The initial tremor and the tremor after the hypotonic period were identical and were estimated to have a frequency of $8-10 \mathrm{~Hz}$. The tremor caused by ibogaine was indistinguishable from that induced by harmaline.

\section{3-AP, harmaline, and nicotinamide regimen}

After administration of 3-AP alone, rats displayed no abnormal motor signs acutely. Injection of harmaline, as part of the 3-AP regimen, rapidly led, within minutes, to a high-frequency generalized tremor and ataxic gait, followed by transient hypotonia, similar to the motor effects produced by ibogaine. The highfrequency tremor gradually disappeared after $\sim 12 \mathrm{hr}$. From the following day until the time of killing, the 3-AP-treated rats exhibited persistently abnormal neurological signs, as described previously (Llinás et al., 1975; Balaban, 1985) and that were not present after ibogaine alone. They became profoundly ataxic and had an unusual steppage gate, described as "mud-walking" (Lli- 

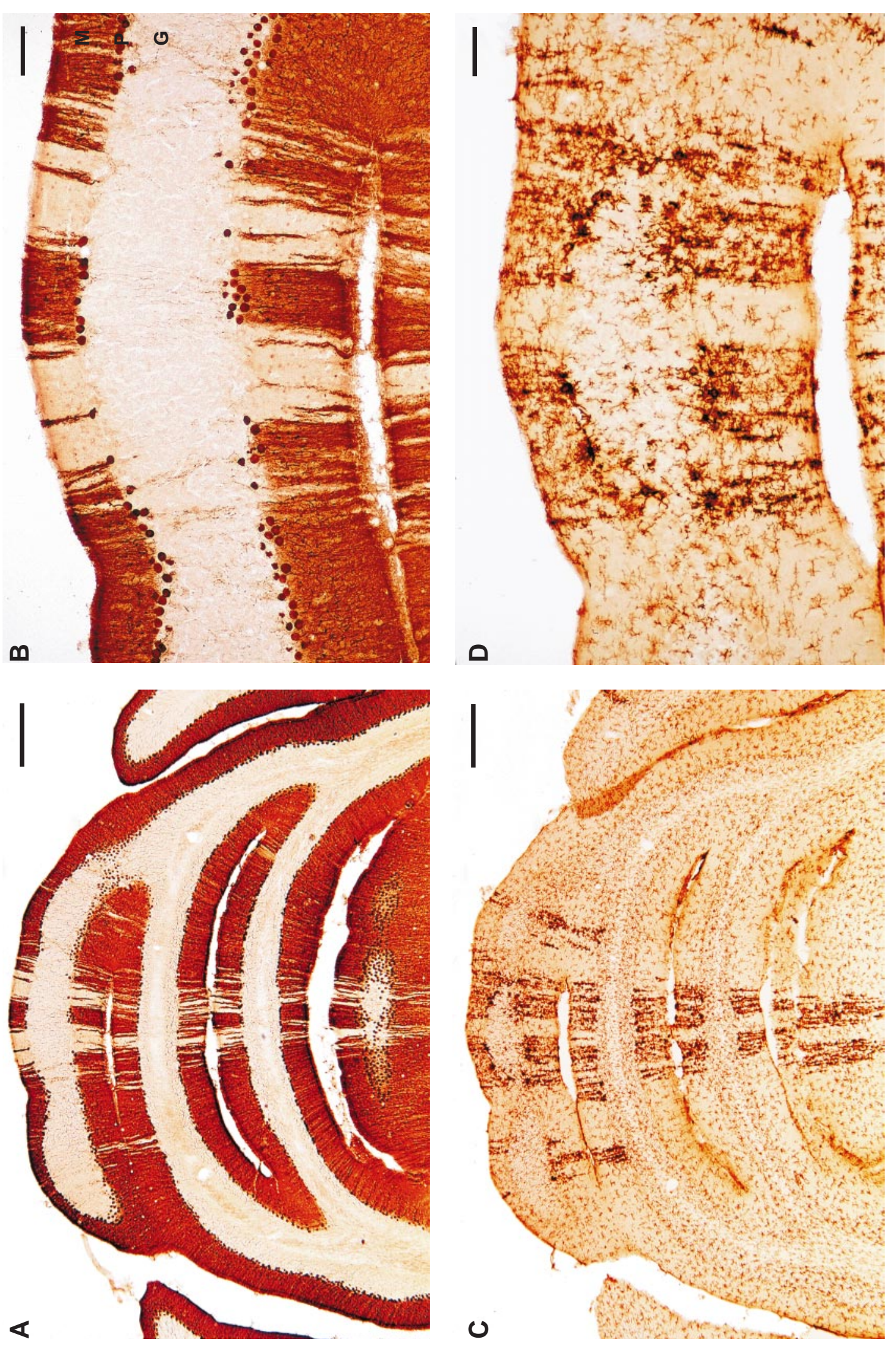

Figure 1. Ibogaine causes degeneration of Purkinje cells and activation of microglia in discrete radial bands of cerebellar cortex. $A$, $B$, Purkinje cells of cerebellar vermis at low $(A)$ and high $(B)$ magnification $7 \mathrm{~d}$ after receiving ibogaine $(100 \mathrm{mg} / \mathrm{kg}$ once). Unstained gaps in the Purkinje cell and molecular layers indicate regions in which Purkinje cells have degenerated (Cam-kin II immunoreactivity, coronal sections). $C$, $D$, Clusters of activated microglial cells form darkly stained radial stripes within the cerebellar vermis, in sections adjacent to those showing Purkinje cells. The stripes containing activated microglia are approximately coextensive with regions of Purkinje cell loss (compare densely stained stripes in C (Figure legend continues) 
nás et al., 1975). Starting $24 \mathrm{hr}$ after treatment with the 3-AP regimen, a brief tremor was observed during the initiation of head or trunk movements. These 3-AP-treated rats differed from those that received ibogaine alone, because the latter displayed no tremor or ataxia beyond $24 \mathrm{hr}$ after treatment.

\section{Ibogaine in 3-AP-, harmaline-, and nicotinamide-pretreated animals}

Rats that received ibogaine 6-d after the 3-AP regimen exhibited myoclonic jerks, brief seizure-like episodes, increased ataxia, and transient hypotonia, as did animals that were given ibogaine alone. However, in 3-AP-treated rats, ibogaine did not produce a high-frequency tremor, unlike normal rats that received ibogaine. After 15 min of hypotonia, there was a gradual return of truncal tone accompanied by ataxia, but the high-frequency tremor was not present. On the day after ibogaine treatment, these rats were indistinguishable from those given the 3-AP and harmaline regimen alone; they displayed ataxia, mud-walking, and a brief tremor on initiation of movement. In summary, in rats treated with the 3-AP regimen, ibogaine produced myoclonus, seizurelike episodes, increased ataxia, and hypotonia, but no sustained tremor, indicating that ablation of the inferior olive prevented the characteristic high-frequency tremor.

\section{Immunohistochemistry}

\section{Cerebellar cortex: control and ibogaine-treated}

Normal, intact Purkinje cells are strongly immunoreactive with antibodies to calbindin or to Cam-kin II, which stain the cell bodies, axons, and dendrites. In untreated control rats, Purkinje cell bodies form an uninterrupted monolayer throughout the cerebellar cortex; the dendrites, which are densely stained, form a network of closely packed processes that extends continuously through the molecular layer. In rats that were administered ibogaine alone, small groups of Purkinje cell bodies and dendrites were selectively lost. At short survivals (1-2 d), irregular, shrunken, and fragmented Purkinje cell bodies were present (E. O'Hearn, unpublished observations). After a 1 week survival, Purkinje cell loss was manifest as multiple pale, radial bands that were unstained with neuronal markers (Fig. $1 A, B$ ). The neurons between these pale bands remained intact and densely stained, as in control rats. Examination of a sequential series of coronal sections revealed clusters of degenerating or absent Purkinje cells aligned in narrow parasagittal rows that typically ranged from one to five Purkinje cells in width. These pale sagittal bands of neuronal loss observed in cerebellar cortex $7 \mathrm{~d}$ after ibogaine treatment spanned the Purkinje cell and molecular layers (Fig. $1 A, B)$. Within these radial bands, Purkinje cell bodies and dendrites were not detectable using antibodies to calbindin or Camkin II. Adjacent Nissl-stained sections revealed small unstained patches in which Purkinje cell bodies were missing; these patches were in register with the gaps in calbindin and Cam-kin II staining seen in neighboring sections. Ibogaine-induced Purkinje cell loss was most prominent in the vermis of the cerebellum, but also included degeneration in the paravermis and, much less commonly, in the hemispheres and paraflocculus.
Activated microglia were detected by intense staining with antibodies to the complement 3 receptor (OX42) (Fig. 1C,D) and to the MHC II antigen (OX6) (data not shown). Cell bodies and processes of activated microglia were enlarged and intensely immunoreactive compared with quiescent microglia located in adjacent zones (Fig. 1D). In control rats, activated microglia were extremely uncommon, whereas the cerebellar cortex of ibogainetreated rats exhibited clusters of large, darkly stained microglial cells located primarily in the molecular and Purkinje cell layers. Activated microglia formed distinct groups that were coextensive with radial bands devoid of Purkinje cell bodies and dendrites, as seen in neighboring sections prepared for Cam-kin II (Fig. 1) or Nissl stain. Both microglial markers (OX6 and OX42) stained the same distribution of activated cells, but in controls the MHC II antigen was expressed by resting microglia primarily in the cerebellar white matter, whereas complement 3 receptor was expressed in resting microglia throughout the cerebellum. In addition, narrow stripes of activated astrocytes (Bergmann glia), densely stained with antibodies to GFAP, were observed in the Purkinje cell and molecular layers (data not shown). These clusters of activated astrocytes were distributed in register with degenerating Purkinje cells and activated microglia.

\section{Inferior olive}

Control inferior olive. In the ventral medulla, neurons expressing calbindin and Cam-kin II were densely packed in lamellae that form the inferior olivary nucleus. Both neuronal markers had the same distribution and appeared to stain all neurons in the inferior olive. Multiple divisions of the inferior olive could be delineated clearly in sections that were immunostained with antibodies to these proteins. Nissl-stained sections revealed abundant ovalshaped neuronal cell bodies and nuclei. In untreated control animals, the inferior olivary nuclei showed no evidence of activated microglia or astrocytes.

Effects of ibogaine alone on inferior olive. After ibogaine administration, neurons of the inferior olivary nucleus, stained with anti-Cam-kin II (Fig. 2A,C), anticalbindin antibodies, or cresyl violet (Fig. $2 E$ ), were unchanged from controls and were normal in density and morphology. Within the inferior olivary nucleus, glial staining with OX42 (Fig. 2G) or GFAP antisera (data not shown) was not increased; inferior olivary microglia and astrocytes were indistinguishable from quiescent glial cells found in control animals.

Effects of 3-AP regimen on inferior olive. After treatment with the cytotoxic 3-AP regimen, nearly all neurons in the inferior olive degenerated. In all 3-AP-treated rats, the region of the medulla containing the inferior olivary nucleus was largely depleted of neuronal cell bodies that were immunopositive for either Cam-kin II (Fig. 2B,D) or calbindin. Nissl-stained sections revealed that the site where the inferior olive is located contained densely packed, small nuclei, presumably of glial cells (astrocytes and microglia) (Fig. $2 F$ ). Notably absent in these sections were the large neuronal nuclei and somata that are present in sections from control (or ibogaine-treated) rats (Fig. 2E). After staining

\section{$\leftarrow$}

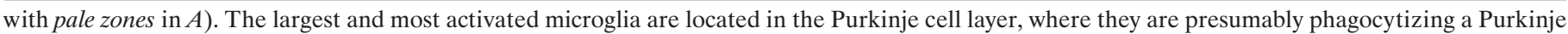

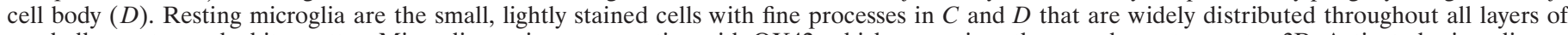

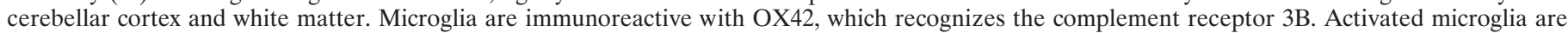

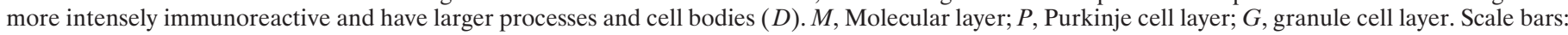
$A, C, 500 \mu \mathrm{m} ; B, D, 100 \mu \mathrm{m}$. 

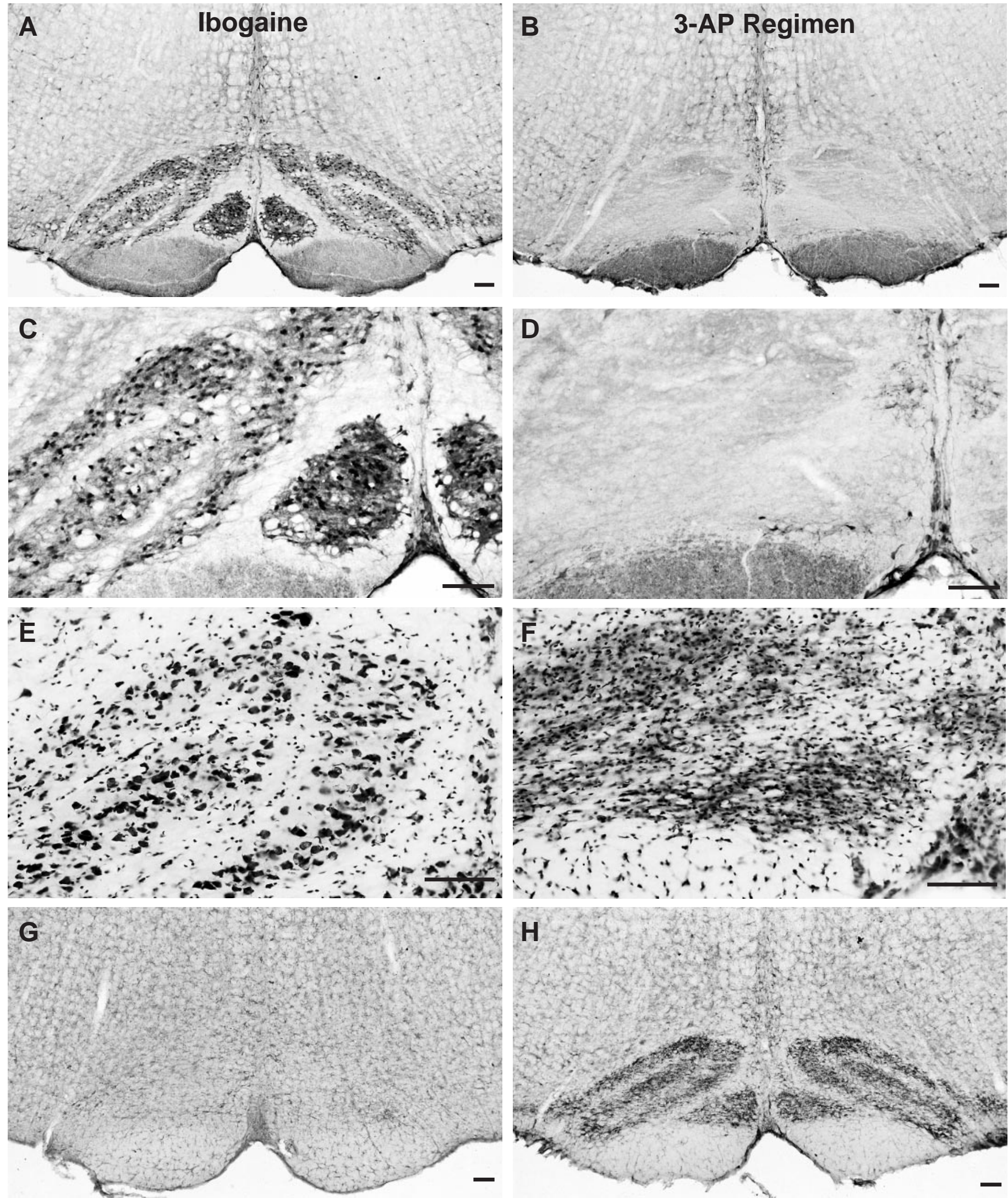

Figure 2. Most neurons in the inferior olivary nucleus degenerate after administration of the 3-AP regimen used in this study. In animals treated with ibogaine alone, inferior olive neurons remain intact and exhibit normal morphology $(A, C)$; in contrast, profound loss of neurons is evident $(B, D)$ in the inferior olive of rats that received the 3-AP regimen (3-acetylpyridine, harmaline, and nicotinamide; $13 \mathrm{~d}$ survival). $A-D$, Inferior olivary nucleus: Cam-kin II immunoreactivity at low $(A, B)$ and high $(C, D)$ magnification. E, Large neuronal cell bodies are shown with Nissl stain of (Figure legend continues) 


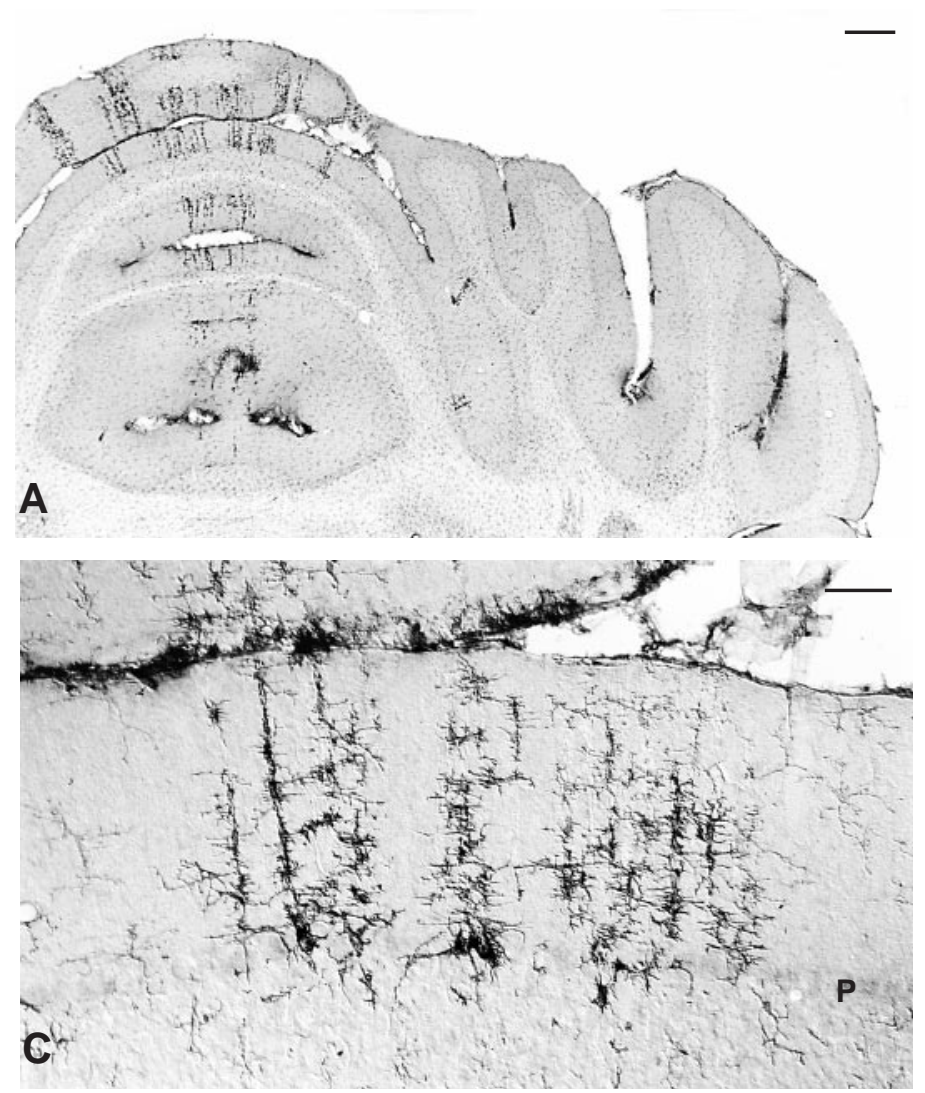

Ibogaine
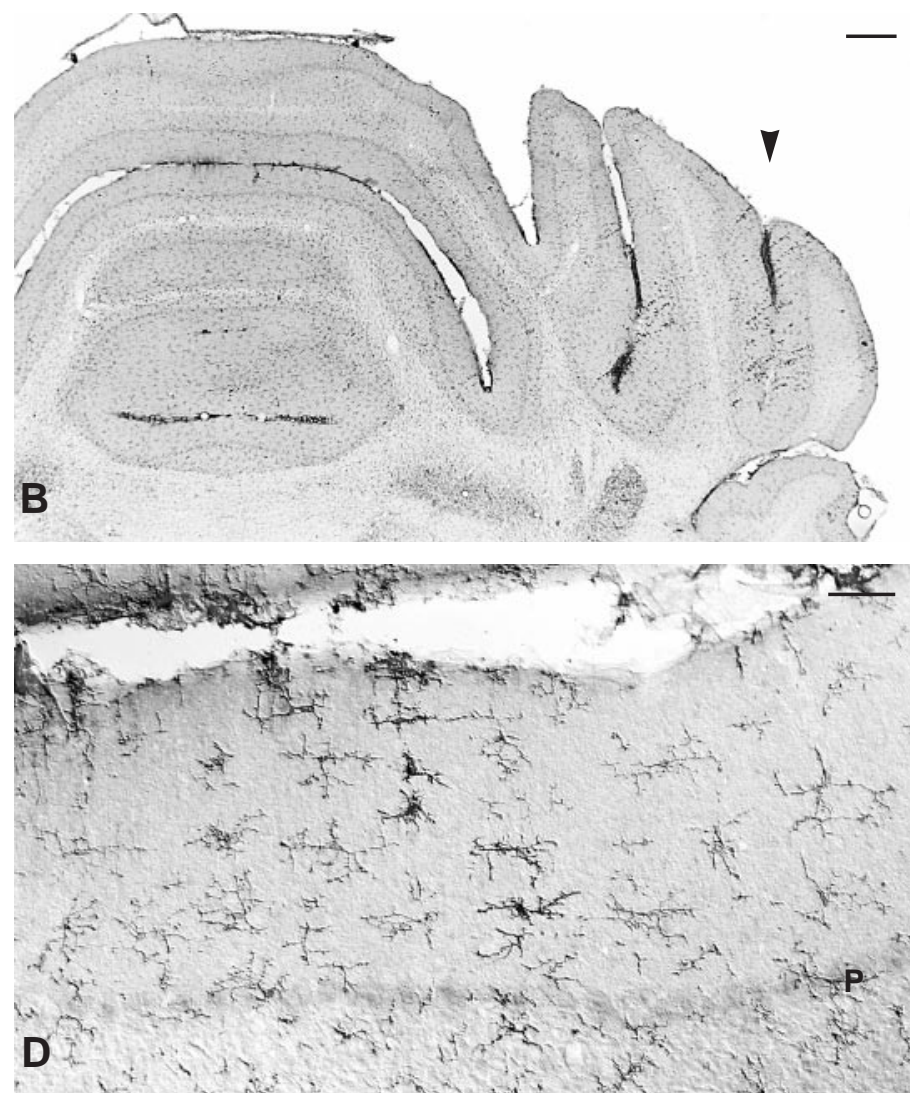

3-AP Regimen

Figure 3. Activated microglia exhibit a different distribution and morphology in ibogaine- versus 3-AP-treated animals. After ibogaine administration $(100 \mathrm{mg} / \mathrm{kg} ; 7 \mathrm{~d}$ survival), activated microglia form radial bands located primarily in the vermis $(A)$; the most intensely activated microglia $(C)$ are found at the depth of Purkinje cell bodies (which have degenerated, as observed in adjacent sections). After the 3-AP regimen (13 d survival), occasional activated microglia are observed far laterally in the hemispheres $(B$, arrowhead), primarily in the ansiform lobule, crus I, and less commonly in the vermis; these activated cells are found mainly in the molecular layer and tended not to be adjacent to Purkinje cell bodies $(D)$. Enlarged, darkly immunoreactive cells are activated microglia. More delicate cellular profiles $(C, D)$ with finer processes, smaller cell bodies, and less intense immunostaining are quiescent microglia. In ibogaine-treated animals, activated microglia $(C)$ are larger and more darkly immunoreactive than those seen after the 3-AP regimen $(D)$, suggesting that 3-AP may cause a smaller degree of neuronal insult. Coronal sections immunostained with antibody OX42 for complement receptor $3 \mathrm{~B}$. Scale bars: $A, B, 500 \mu \mathrm{m} ; C, D, 50 \mu \mathrm{m}$. $P$, Purkinje cell layer.

with a microglial marker (OX42), sections through this region demonstrated that olivary neurons had been replaced by numerous, intensely activated microglial cells that were densely packed in a gliotic zone that resembled the inferior olivary nucleus in location and shape, as shown in Figure $2 H$.

Effects of 3-AP regimen, followed by ibogaine, on inferior olive. In animals that received the 3-AP regimen, followed 1 week later by ibogaine, no further changes were detected in the inferior olive. Rats treated with the 3-AP regimen alone were compared with rats given 3-AP plus ibogaine. Sections of the inferior olive from the two groups were indistinguishable. As noted above, nearly all olivary neurons were ablated by the 3-AP regimen and were replaced by activated glial cells. In both 3 -AP treatment groups, microglia and astrocytes in the inferior olivary nucleus were consistently enlarged and strongly immunoreactive to glial antibodies (GFAP, OX42, and OX6).

In 22 of 26 rats that received the 3-AP regimen, with or without ibogaine, a small contingent of calbindin- or Cam-kin IIimmunoreactive neurons remained in the inferior olive. These surviving neurons, in small numbers, were found in particular subdivisions of the olivary complex. Spared cells were typically confined to the medial accessory olive and an occasional neuron survived within the dorsal accessory olive or the principal olive.

rats $(E)$, whereas smaller profiles are glial cells. $F$, After the 3-AP regimen, neuronal profiles in the inferior olive are absent, and this nucleus has become densely populated with small glial cell bodies. The inferior olive is gliotic because of proliferation of astrocytes and microglia that were activated in response to degeneration of inferior olive neurons. Using a marker for microglial cells $(G, H)$, only lightly stained, resting microglia are observed in the inferior olive from an ibogaine-treated rat $(G)$; in contrast, after the 3-AP regimen, densely packed activated microglia occupy the site of the former inferior olivary nucleus $(H)$ and demarcate the different subregions that were present in this nucleus. Cytochemical markers and stains: $A-D$, Cam-kin II immunocytochemistry for inferior olive neurons; $E, F$, Nissl stain of inferior olive; $G, H$, to identify microglia, the inferior olive is stained with antibody (OX42) that recognizes the complement receptor 3B. This receptor is expressed at moderate levels by quiescent microglia and is greatly increased in activated microglia in response to neuronal injury or degeneration. Scale bars: $A-H, 100 \mu \mathrm{m}$. 


\section{Cerebellar cortex after ablation of inferior olive}

Effects of 3-AP regimen on cerebellar cortex. In the 3-AP-treated rats, as in controls, Purkinje cell bodies formed a monolayer throughout the cerebellar cortex. Neuronal morphology after 3-AP could not be distinguished from that in control rats, as seen in sections stained for Nissl or for other neuronal markers. The molecular layer, containing dendrites of Purkinje cells and other neurons, was well stained with antisera to Cam-kin II and calbindin. However, a minor effect of the 3-AP regimen could be detected on close examination. Two weeks after 3-AP treatment, there were signs suggesting that a small number of individual Purkinje cells were missing. Sections stained for Cam-kin II occasionally revealed a narrow unstained radial band across the molecular and Purkinje cell layers with a width equal to one Purkinje cell. Such bands were infrequent and appeared to be located primarily in the lateral portion of the hemispheres.

Resting microglia, immunostained for OX42, were observed throughout cerebellar cortex in both 3-AP-treated and control rats. After receiving 3-AP, a thin radial column of mildly activated microglia was occasionally found in the molecular layer (Fig. 3B,D) but generally did not extend into the Purkinje cell layer (Fig. 3D). Columns of activated microglia were infrequent and nearly always one cell in width, when present. Thin microglial columns seen after 3-AP were predominantly located not in the vermis, but in the lateral part of the cerebellar hemisphere, mainly in crus I of the ansiform lobule (Fig. 3B,D). These microglia were darker than resting microglia but typically were less intensely stained or enlarged than the highly activated microglia seen after ibogaine (Figs. $1 C, D, 3 A, C$ ). The cytotoxic effects of the 3 -AP regimen in the cerebellum were subtle and differed markedly from the effects of ibogaine. In rats that received ibogaine alone, dense columns of activated microglia were found primarily in the vermis (Figs. $1 C, 3 A$ ) and in the medial part of the simple lobule, unlike the more lateral distribution seen in 3-AP-treated rats (Fig. 3B,D). Moreover, the largest and most intensely activated microglial cells after ibogaine were located at the level of Purkinje cell bodies (Figs. 1D, 3C); in contrast, 3-AP-induced glial activation did not usually extend down to the Purkinje cell layer (Fig. 3D). In addition, after 3-AP treatment there were occasional thin radial stripes of increased GFAP in the molecular layer (data not shown). The preceding results suggest that the 3-AP regimen alone may have caused loss of an occasional neuron (Purkinje, stellate, or basket cell), yet neuronal damage attributed to the 3-AP regimen was orders of magnitude less than that produced by ibogaine. In addition, the distribution of neuronal cell loss and glial activation differed between animals that received ibogaine versus the 3 -AP regimen. In summary, neuronal damage after the 3-AP regimen was typically found in lateral parts of the hemispheres rather than in the vermis (Fig. $3 B, D)$, in contrast to degeneration induced by ibogaine, which was located predominantly in the vermis (Figs. 1, 3A). At the 2 week survival time, when 3-AP-treated animals were studied, there was no evidence of widespread microglial activation that could be ascribed to loss of climbing fibers.

Effects of 3-AP regimen, followed by ibogaine, on cerebellar cortex. Ablation of the inferior olivary nucleus with the 3-AP regimen markedly attenuated Purkinje cell degeneration caused by subsequent ibogaine treatment (Figs. 4, 5). Rats that received ibogaine alone were compared with those that received the 3-AP regimen followed by ibogaine $6 \mathrm{~d}$ later. In both experimental groups, the survival time after ibogaine administration was 1 week. After administration of 3-AP before ibogaine, Purkinje cell loss was markedly reduced (Fig. 4); in contrast to the prominent bands of neuronal loss that followed treatment with ibogaine alone (Fig. 4A,C,E), zones of missing Purkinje cells were nearly absent in the vermis of animals that received 3-AP plus ibogaine (Fig. 4B,D,F). This neuroprotective effect of olive ablation was seen in 17 of 17 animals that were treated with the 3-AP regimen before ibogaine. Yet, protection against Purkinje cell degeneration in these rats was not absolute, because a thin band of neuronal degeneration was occasionally found in the vermis or hemisphere. The minimal neurotoxicity found after 3-AP plus ibogaine was detected by the presence of infrequent narrow bands unstained with neuronal markers, located predominantly in the lateral part of the hemisphere. This distribution of cell loss in the lateral hemisphere is similar to the loss observed in animals that received the 3-AP regimen by itself. In contrast, rats that received ibogaine alone exhibited numerous radial gaps in staining, mainly in the vermis where Purkinje cells had degenerated, as seen in calbindin, Cam-kin II (Figs. $1 A, B, 4 A, C, E$ ), and Nissl sections.

The distribution of activated microglia and astrocytes paralleled that of neuronal loss. Compared with the effects of ibogaine alone, microglial activation was markedly decreased in rats that received the 3-AP regimen followed by ibogaine (Fig. 5B,D,F). These animals exhibited only occasional radial stripes of activated microglia; the few glial stripes present were narrow and were located either in the vermis or in the lateral part of the hemisphere. The lateral microglial stripes were primarily situated in the ansiform lobule, the same location where activated microglia were also found after the 3-AP regimen alone (Fig. 3B,D). These results show that previous ablation of the inferior olive by 3 -AP almost completely prevented ibogaine-induced degeneration of Purkinje cells and activation of neighboring glial cells. The lateral position of residual neuronal damage observed after 3-AP plus ibogaine may result from toxicity caused by the 3-AP regimen itself, before administration of ibogaine.

\section{3-AP toxicity in other brain sites}

In agreement with previous studies, evidence suggesting minor 3-AP-induced neuronal injury was seen in regions outside of the cerebellar cortex. After the 3-AP treatment regimen, moderately increased OX42 staining indicative of activated microglia was found in the deep cerebellar nuclei in addition to other brainstem nuclei, which included the lateral vestibular, dorsal cochlear, ambiguus, and hypoglossal nuclei (data not shown). 3-APinduced activation of microglial cells in the deep cerebellar nuclei (fastigial, interposed, and dentate) produced an equivalent degree of enhanced microglial staining across these three nuclei. This distribution of activated glial cells differed from that observed after ibogaine alone, in which the fastigial nucleus contained significantly more prominent microglial activation than did the interposed or dentate nuclei (data not shown). In ibogainetreated rats there were no neuronal changes in Nissl-stained sections of the deep cerebellar nuclei, suggesting that microglial activation in these nuclei resulted from degeneration of axon terminals, quite likely those arising from Purkinje cells. Gliosis predominantly in the fastigial nucleus is consistent with degeneration of Purkinje cells in the vermis, the main location of neurotoxicity.

\section{DISCUSSION}

Systemic administration of ibogaine in rats produces cerebellar neurotoxicity manifested by the selective loss of a small population 

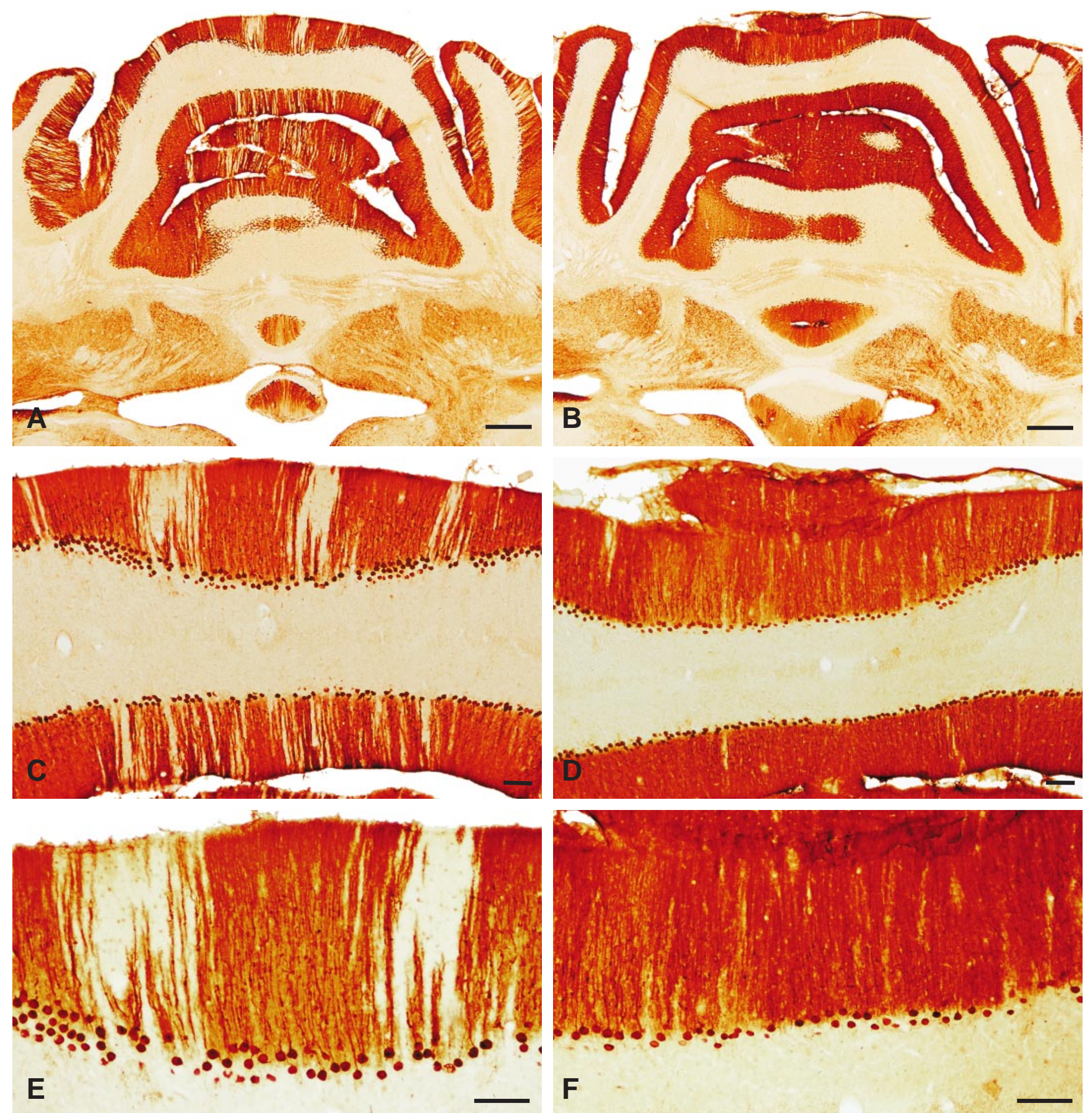

\section{lbogaine}

\section{3-AP regimen + Ibogaine}

Figure 4. $A-F$, Neuroprotection: ablation of the inferior olive with 3-AP prevents or greatly attenuates Purkinje cell degeneration induced by ibogaine. Left column $(A, C, E)$, Treatment with ibogaine alone produces radial bands of Purkinje cell loss manifested by pale, unstained gaps in the molecular and Purkinje cell layers. Loss of Purkinje cells is most prominent in the vermis but is also present in the paravermis and simplex lobule. Right column $(B, D, F)$, Animals that received the 3-AP regimen followed by ibogaine $6 \mathrm{~d}$ later demonstrate marked neuroprotection against Purkinje cell degeneration. The nearly continuous immunostaining of Purkinje cell bodies and of their dendrites in the molecular layer $(B, D, F)$ indicates that there is little or no ibogaine-induced degeneration of Purkinje cells after olive ablation. Infrequently in rats that received the 3-AP regimen plus ibogaine, a single Purkinje cell may have degenerated (see thin gap in neuronal staining of molecular and Purkinje cell layers in upper right corner of D). Photomicrographs show Purkinje cells in coronal sections immunostained with antiserum to Cam-kin II. Ibogaine dose, $100 \mathrm{mg} / \mathrm{kg}$ once; in all cases, survival was $7 \mathrm{~d}$ after ibogaine administration. Scale bars: $A, B, 500 \mu \mathrm{m} ; C-F, 100 \mu \mathrm{m}$. 

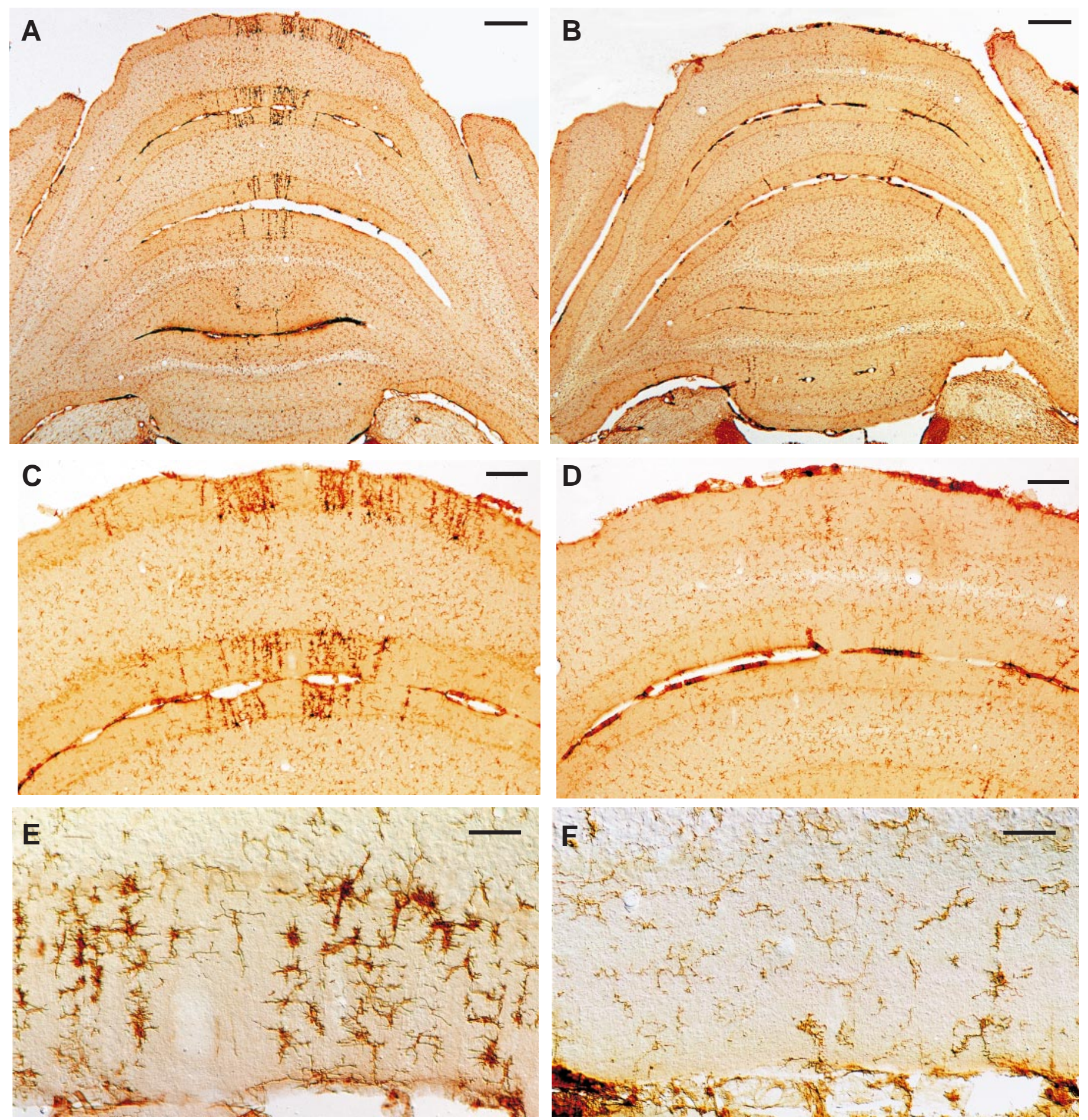

lbogaine

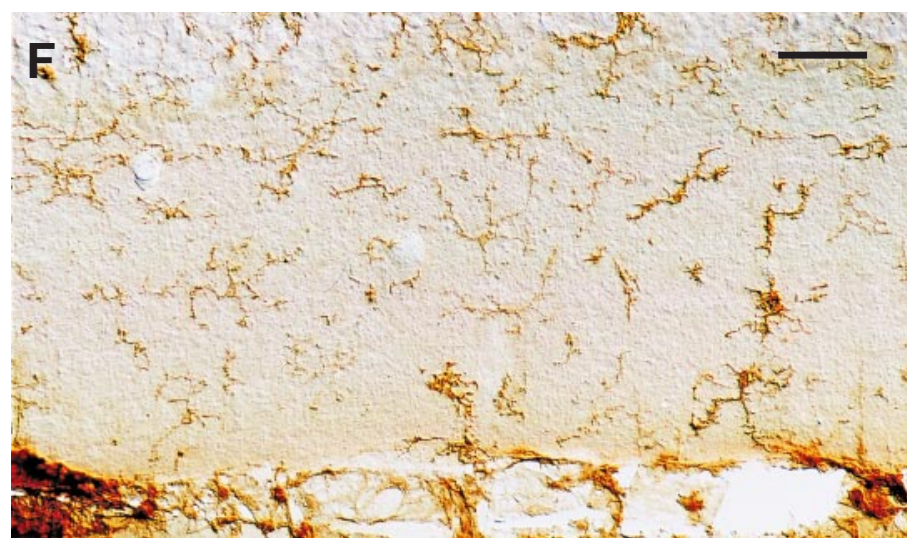

\section{3-AP regimen + Ibogaine}

Figure 5. Ablation of the inferior olive with the 3-AP regimen profoundly attenuates subsequent microglial activation induced by ibogaine. Left column $(A, C, E)$, Treatment with ibogaine alone produces radial bands of darkly stained, activated microglia, primarily in the molecular and Purkinje cell layers of the cerebellar vermis. In most cases, the radial bands of microglia are coextensive with bands of degenerating Purkinje cells (Fig. 1). Right column (B, $D, F)$, Animals that received the 3-AP regimen followed by ibogaine $6 \mathrm{~d}$ later demonstrate few signs of microglial activation. After the 3-AP regimen, ibogaine no longer produces more than an occasional radial stripe of activated microglia. The great majority of cells seen are resting microglia that are faintly stained and have delicate processes. Activated microglia are infrequent in the rats that received the 3-AP regimen plus ibogaine. Photomicrographs of coronal sections show microglial cells immunostained with antiserum OX42 for complement receptor 3B. Drug doses: $A$, $C, E$, ibogaine (100 $\mathrm{mg} / \mathrm{kg}) ; B, D, F, 3$-AP regimen given $6 \mathrm{~d}$ before ibogaine $(100 \mathrm{mg} / \mathrm{kg})$. In all cases, survival was $7 \mathrm{~d}$ after ibogaine administration. Scale bars: $A, B, 500$ $\mu \mathrm{m} ; C, D, 100 \mu \mathrm{m} ; E, F, 50 \mu \mathrm{m}$. 
of Purkinje cells (O’Hearn and Molliver, 1993). Purkinje cells that undergo degeneration are distributed in discrete longitudinal rows that are coextensive with bands of activated microglia and astrocytes (O'Hearn et al., 1993). These multiple bands of neuronal degeneration, which form radial stripes within the molecular and Purkinje cell layers, are found predominantly in the vermis but infrequently in the paravermis and cerebellar hemispheres (O'Hearn and Molliver, 1993; Molinari et al., 1996). The main new finding of this investigation is that ablation of the inferior olivary nucleus by 3-AP prevents subsequent ibogaine-induced Purkinje cell degeneration. This result leads to the conclusion that ibogaine is not directly toxic to Purkinje cells but instead causes Purkinje cell degeneration through sustained activation of the olivocerebellar projection. This paper presents evidence that ibogaine-induced Purkinje cell degeneration provides an experimental in vivo paradigm of trans-synaptic, excitotoxic neuronal degeneration, which is mediated through intrinsic olivocerebellar circuitry.

The spatial pattern of Purkinje cell loss induced by ibogaine supports a primary role for the olivocerebellar projection in producing this form of neurotoxicity. The longitudinal band-like distribution of Purkinje cell degeneration caused by ibogaine corresponds to the sagittal organization of inferior olive-Purkinje cell innervation. Earlier studies revealed that the inferior olive projects topographically to longitudinal zones of cerebellar cortex (Oscarsson, 1976) such that small clusters of olivary neurons innervate Purkinje cells that are aligned in parasagittal rows that are hundreds of micrometers wide (Groenewegen and Voogd, 1977; Brodal and Kawamura, 1980; Azizi and Woodward, 1987). By recording from multiple Purkinje cells simultaneously, Llinás and colleagues elegantly demonstrated that climbing fiber activation occurs synchronously in Purkinje cells that lie in rostrocaudal rows (Llinás and Sasaki, 1989; Sasaki et al., 1989). These longitudinally oriented, physiological "microzones" are narrower than the zones defined anatomically, encompassing from one to several Purkinje cells. Moreover, clusters of inferior olivary neurons are electrotonically coupled by gap junctions (Llinás et al., 1974; Sotelo et al., 1974; Llinás and Yarom, 1986) and synchronously excite Purkinje cells in the same longitudinal row (Llinás and Sasaki, 1989; Sasaki et al., 1989).

We postulate that the principal effect of ibogaine, like the related compounds harmaline and ibogaline (Fig. 6), is to increase the activity of neurons in the inferior olive. These three drugs have similar behavioral and pharmacological effects, and all of them produce a marked tremor. Several lines of evidence suggest that the tremor induced by these indole alkaloids results from excitation of inferior olivary neurons. The most thoroughly characterized of these drugs is harmaline, which causes a sustained $8-12 \mathrm{~Hz}$ generalized tremor in all species tested, including mice (Zetler, 1957), rats (Zetler et al., 1972, 1974), cats (Lamarre et al., 1971), and monkeys (Battista et al., 1990). Ibogaline and ibogaine produce an identical 8-12 Hz tremor in mice (Zetler et al., 1972) and in cats (De Montigny and Lamarre, 1974). In addition, harmaline induces sustained rhythmic activation of inferior olivary neurons when given systemically (Lamarre et al., 1971; De Montigny and Lamarre, 1973; Llinás and Volkind, 1973), when microinjected directly onto inferior olive neurons in vivo (De Montigny and Lamarre, 1975), or when applied by superfusion of the inferior olive in slices (Llinás and Yarom, 1986). Harmaline-treated animals demonstrate synchronous, rhythmic bursts of activity $(8-12 \mathrm{~Hz})$ throughout the spinocerebellar system, including inferior olive, Purkinje cells, deep cerebellar nuclei, reticular formation, and motoneurons (Lamarre<smiles>COc1ccc2c3c([nH]c2c1)C(C)=NCC3</smiles><smiles></smiles>

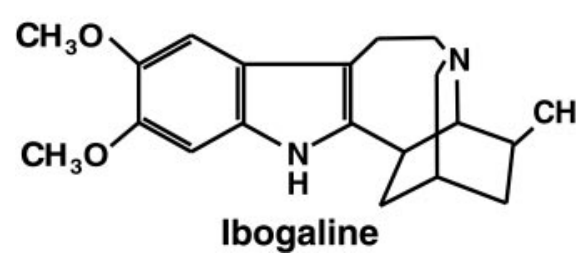

Figure 6. Chemical structures of the indole alkaloids harmaline, ibogaine, and ibogaline. Harmaline, ibogaine, and ibogaline share an indole nucleus and have nearly identical types of behavioral effects. Zetler et al. $(1972,1974)$ reported that the positions and number of methoxy groups (left) greatly influence tremorigenic potency, whereas the additional ring structures (right) have little effect on drug action within this group of compounds. For comparative potencies of tremor induction, see Zetler et al. $(1972,1974)$.

and Mercier, 1971; Lamarre et al., 1971; Lamarre and Weiss, 1973; Llinás and Volkind, 1973). Bursts of rhythmic neuronal activity are time-locked to the harmaline-induced tremor, as assessed by electromyographic recording (De Montigny and Lamarre, 1973; Milner et al., 1995). These data indicate that the tremor is induced by rhythmic activation of motoneurons attributable to entrainment of brainstem descending pathways by the olivocerebellar rhythm. Initial proposals that the harmaline tremor originates in inferior olivary neurons have received considerable experimental support. Lesions that interrupt connections between the inferior olive and cerebellum prevent the harmaline tremor but do not block drug-induced activation of inferior olivary neurons (Lamarre and Mercier, 1971; De Montigny and Lamarre, 1973; Llinás and Volkind, 1973). Chemical ablation of the inferior olive by 3-AP also prevents harmalineinduced tremor (Simantov et al., 1976).

This laboratory reported previously that both ibogaine and harmaline have similar behavioral effects and produce the same pattern of Purkinje cell degeneration (O'Hearn and Molliver, 1993). Based on their structural similarities (Fig. 6) and identical behavioral and neurotoxic effects, it is likely that ibogaine, like harmaline, acts directly on inferior olivary neurons to initiate synchronous rhythmic activity. The present results show that olive ablation prevents ibogaine-induced tremor, supporting the proposal that ibogaine acts on the inferior olive. However, the finding that ibogaine produces hypotonia despite olive ablation suggests that the hypotonia is not mediated by the olivocerebellar projection, and that this drug acts at additional CNS sites. Other sites of ibogaine action were suggested by extensive c-Fos induction caused by ibogaine given after inferior olive ablation (O'Hearn and Molliver, 1994). 
Although harmaline and related drugs clearly produce activation of olivary neurons, particular subdivisions of the inferior olivary complex differ in their susceptibility to this effect. This regional selectivity may partially explain the localization of ibogaine toxicity to the vermis. Both harmaline and ibogaline activate neurons preferentially in caudal portions of the medial and dorsal accessory olivary subnuclei (De Montigny and Lamarre, 1973, 1974; Llinás and Volkind, 1973; Batini et al., 1981), regions of the inferior olive that project selectively on the vermis (Groenewegen and Voogd, 1977; Brodal and Kawamura, 1980; Azizi and Woodward, 1987; Buisseret-Delmas and Angaut, 1993). Moreover, dendro-dendritic gap junctions, which likely contribute to rhythmic activation, are primarily located in a restricted portion of the medial inferior olive (de Zeeuw et al., 1996). The specific mechanism by which this class of compounds increases excitability and inferior olive firing (from $1-2$ to $8-12 \mathrm{~Hz}$ ) is not fully established, yet Llinás and Yarom (1986) have demonstrated that harmaline leads to hyperpolarization of olivary neurons and facilitates calcium conductance through low threshold calcium channels.

The present results suggest that the distribution of climbing fibers in sagittal bands determines the spatial pattern of degeneration induced by ibogaine. Moreover, the uniquely dense synaptic relationship of climbing fibers with Purkinje cells is likely to underlie the potential for neuronal injury in this system. Climbing fibers arise exclusively from inferior olivary neurons (Szentágothai and Rajkovits, 1959; Desclin, 1974), and each Purkinje cell is innervated by a single climbing fiber from the contralateral inferior olive. Climbing fiber axons pass over the Purkinje cell body and form branches that closely follow the proximal twothirds of Purkinje cell dendrites (Eccles et al., 1967; Palay and Chan-Palay, 1974). Each climbing fiber forms several hundred synaptic contacts on dendritic spines distributed over one Purkinje cell (Llinás et al., 1969), resulting in a unique and extensive excitatory synaptic input. This "distributed" synaptic arrangement provides a structural basis for the powerful excitatory action of climbing fibers on Purkinje cells (Eccles et al., 1966a,b). Every climbing fiber action potential results in nearly synchronous release of glutamate, the most likely transmitter of olivary neurons (Zhang et al., 1990), at hundreds of synapses distributed over the surface of the Purkinje cell dendritic tree. The release of glutamate simultaneously at every synaptic terminal on a Purkinje cell produces "complex spikes," consisting of an initial spike followed by a high-frequency burst of smaller calcium-mediated action potentials (Eccles et al., 1966a,b; Llinás and Nicholson, 1971; Llinás and Sugimori, 1980). The multiplicity of climbing fiber synapses is responsible for the highly secure synaptic transmission in this projection, yet this synaptic relationship also places the Purkinje cell in substantial jeopardy of excitotoxic injury.

Based on the hypothesis that ibogaine, like harmaline and ibogaline, causes a sustained increase in frequency of neuronal firing in the inferior olive, we propose that this property, combined with the highly secure synaptic relationship between climbing fibers and Purkinje cells, results in Purkinje cell injury by an excitotoxic mechanism. We further postulate that the distributed nature of climbing fiber-Purkinje cell innervation renders Purkinje cells especially susceptible to excitotoxic injury and may be the basis for the heightened vulnerability of Purkinje cells to a wide variety of insults. The incidence of Purkinje cell loss in humans is disproportionate to the loss of other neurons after hypoxia or ischemia, prolonged seizures, exposure to numerous toxins, in normal aging, and in several neurodegenerative disorders (Blackwood and Corsellis, 1976; Adams and Duchen, 1992).
Excitotoxic neuronal injury is proposed to result from intense and prolonged glutamatergic excitation that produces excessive elevation of intracellular calcium, leading to activation of multiple calcium-dependent enzymes that damage cellular constituents (Olney et al., 1971; Olney, 1978; Garthwaite et al., 1986; Choi, 1987, 1988; Siman and Noszek, 1988). Activation of Purkinje cells by climbing fibers can lead to elevation of cytosolic calcium levels by several mechanisms. Glutamate receptors that are postsynaptic to climbing fiber terminals are of the non-NMDA (AMPA or kainate) (Konnerth et al., 1990; Perkel et al., 1990), or metabotropic receptor subtype (Masu et al., 1991; Martin et al., 1992; Baude et al., 1993). Although NMDA receptors are expressed transiently by Purkinje cells during early development, in mature animals Purkinje cells do not exhibit functional NMDA receptors (Crepel et al., 1982; Perkel et al., 1990; Crepel and Audinat, 1991; Rosenmund et al., 1992), and they would therefore not play a role in neurotoxicity attributed to ibogaine or harmaline.

Glutamate activation of AMPA receptors on Purkinje cells produces influx of sodium, leading to membrane depolarization, secondarily allowing influx of extracellular calcium through voltage-sensitive calcium channels (Kostyuk, 1990; Bertolino and Llinás, 1992; Miyakawa et al., 1992). Additionally, a subset of AMPA receptors is capable of transmitting calcium directly, in addition to sodium and potassium (Sorimachi, 1993; Brorson et al., 1994; Jonas et al., 1994). Stimulation of metabotropic receptors on Purkinje cells leads to the formation of inositol 1,4,5-trisphosphate, which produces release of calcium from storage vesicles in endoplasmic reticulum (Ross et al., 1989; Satoh et al., 1990; Llano et al., 1991). Thus, repetitive and prolonged climbing fiber activation, through the combination of several postsynaptic mechanisms, is capable of producing massive increases in levels of intracellular calcium throughout the Purkinje cell cytoplasm, in both soma and dendrites. These sustained high concentrations of cytosolic calcium are capable of activating intracellular enzymes, such as lipases and proteases, that may initiate a proteolytic cascade leading to Purkinje cell degeneration (Brorson et al., 1994; Orrenius et al., 1996).

\section{Other Interpretations}

Although the most likely interpretation of the present results is that ibogaine-induced Purkinje cell degeneration is transsynaptically mediated via the olivocerebellar projection, the possible involvement of other mechanisms and factors should be considered. (1) Ibogaine might have a direct, deleterious effect on Purkinje cells that could impair their response to excessive excitatory input and, combined with increased climbing fiber activation, may contribute to degeneration. Sparing of Purkinje cells and the preservation of their normal morphology in rats that received ibogaine after ablation of the inferior olive does not lend support to this interpretation. Moreover, it is unlikely that ibogaine has direct neurotoxic effects, because it did not produce signs of neuronal injury in the inferior olive, a region in which the drug has significant physiological effects. However, it is difficult to exclude the possibility that ibogaine may have an undetected neurotoxic effect that produces no morphological or immunocytochemical changes. (2) An alternative explanation for these data is that, in addition to sustained climbing fiber activation because of ibogaine, the presence of severe tremor might indirectly lead to increased activity in parallel fibers. The combination of increased climbing and parallel fiber activity together may contribute to Purkinje cell injury. Two factors make this explanation unlikely: (A) harmaline causes sustained rhythmic bursts of complex spikes in Purkinje cells, during which "simple spikes," the signs of 
parallel fiber synaptic input, are suppressed (Lamarre et al., 1971); and (B) parallel fibers traverse the folium in a mediolateral direction, at right angles to the rows of degenerating Purkinje cells, whereas the sagittal bands of degeneration match the distribution of climbing fibers. (3) A third caveat arises from reports that neuronal injury after 3-AP may not be restricted to inferior olive neurons. Several neuronal groups are reported to degenerate after treatment with 3-AP, including nucleus ambiguus, hypoglossal nuclei, dorsal motor nucleus of vagus, interpeduncular nuclei, substantia nigra, ventral tegmental area, and dentate gyrus (Balaban, 1985). If Purkinje cell degeneration was increased by activity in these nuclei, then previous administration of 3-AP might theoretically attenuate the neurotoxic effects of ibogaine on Purkinje cells. However, none of the other neuronal groups that may be injured by 3-AP is known to innervate Purkinje cells directly. Moreover, the 3-AP regimen used in this study, which includes a small dose of harmaline followed by nicotinamide, is thought to maximize the selectivity of degeneration in the inferior olive (Llinás et al., 1975). Although these alternative explanations cannot be completely excluded, the most parsimonious interpretation of the present results is that ibogaine causes excitotoxic Purkinje cell degeneration mediated via the olivocerebellar projection.

\section{Sparing of inferior olive neurons}

Although ablation of the inferior olive with 3-AP affords substantial protection against Purkinje cell degeneration, the attenuation is not complete, because loss of an occasional Purkinje cell was observed in some rats that received the 3-AP regimen before ibogaine. Relevant to this finding is that not all neurons in the inferior olive degenerated in every animal that received the 3-AP regimen. The relatively few inferior olivary neurons that survived 3-AP treatment were most commonly located within the medial accessory olive. Differential susceptibility of inferior olivary neurons to the 3-AP regimen has been reported previously, with surviving neurons found most frequently in caudal portions of the inferior olive, especially in the medial accessory olive (Llinás et al., 1975; Anderson and Flumerfelt, 1984; Rossi et al., 1991), which is known to project to the vermis (Brodal, 1954). The persistence of these olivary neurons, along with their climbing fiber projections to the cerebellum, might contribute to the infrequent ibogaine-induced degeneration of Purkinje cells that was observed in the vermis of some 3-AP-treated animals.

Relevant to interpreting sporadic Purkinje cell degeneration after ablation of the olive is the finding that a small number of Purkinje cells degenerate after treatment with the 3-AP regimen alone, a result not reported previously. After the 3-AP regimen, occasional narrow gaps in Purkinje cell staining in the vermis and ansiform lobule (crus I) were coupled with similarly infrequent radial bands of activated microglia, a combination suggesting Purkinje cell damage. Compared with degeneration caused by ibogaine, Purkinje cell loss resulting from the 3-AP regimen alone is considerably less, and neuronal degeneration produced by these two drugs is dissimilar in distribution. After the 3-AP regimen, Purkinje cell damage is located mainly in the lateral part of the hemispheres, whereas ibogaine induces neuronal death primarily in the vermis. After receiving 3-AP plus ibogaine, Purkinje cell loss, although infrequent, was slightly more common in the vermis than after 3-AP alone; however, no increase in degeneration was appreciated in the lateral part of the hemispheres compared with that caused by 3-AP alone. Based on this combination of results, much of the Purkinje cell loss after treatment with 3-AP plus ibogaine likely results from cytotoxicity of the 3-AP regimen itself, which includes a low dose of harmaline. Alternatively, the additional Purkinje cell degeneration in the vermis may be because of ibogaine-induced activation of spared inferior olivary neurons.

Ablation of the inferior olivary nucleus with subsequent degeneration of climbing fibers may result in altered Purkinje cell activity and morphology that should be considered in interpreting the present data. The removal of climbing fibers leads to Purkinje cell changes that might possibly render those cells less sensitive to cytotoxic injury. Within minutes after climbing fiber deafferentation, Purkinje cells double the frequency of simple spikes, and the firing pattern becomes significantly more regular compared with Purkinje cells with intact climbing fibers (Colin et al., 1980). The increase in simple spike activity persists for several weeks after olive ablation (Benedetti et al., 1984). Six days after the 3-AP regimen, the time point when ibogaine was administered in this study, deafferented Purkinje cells would likely be firing simple spikes at rates well above normal. It is unlikely that the increased firing rate would protect Purkinje cells against the toxic effects of ibogaine.

In addition to increased activity after climbing fiber ablation, deafferented Purkinje cells undergo morphological changes. Climbing fibers are required for maintenance of normal Purkinje cell dendritic structure (Sotelo et al., 1975; Bradley and Berry, 1976). Climbing fiber deafferentation induced by 3-AP occurs within 18-24 hr (Desclin and Escubi, 1974; Sotelo et al., 1975) and is followed by an increase in the density of spines on secondary and tertiary dendritic branches of the Purkinje cells. The increase in dendritic spines would not predictably diminish excitotoxic vulnerability of these cells. Possible axonal regeneration may also affect the neurotoxicity. Partial inferior olive ablation is followed by sprouting of new collaterals that reinnervate neighboring Purkinje cells (Rossi et al., 1991). Although reinnervation might be expected to favor Purkinje cell degeneration mediated by surviving climbing fibers, the sprouting takes longer than $6 \mathrm{~d}$ and would not likely be functional at the time of ibogaine administration in this study. Although climbing fiber deafferentation is followed by changes in Purkinje cell structure and function, none of these is reasonably expected to be neuroprotective to Purkinje cells. Taken together, the present results demonstrate that Purkinje cell degeneration attributed to ibogaine is indirect, mediated by the olivocerebellar projection. This example of neurotoxicity, using intrinsic circuitry that uses glutamate as neurotransmitter, supports the hypothesis that ibogaine causes trans-synaptic, excitotoxic neuronal degeneration.

\section{REFERENCES}

Adams JH, Duchen LW (1992) Greenfield's neuropathology. New York: Oxford UP.

Anderson WA, Flumerfelt BA (1980) A light and electron microscopic study of the effects of 3-acetylpyridine intoxication on the inferior olivary complex and cerebellar cortex. J Comp Neurol 190:157-174.

Anderson WA, Flumerfelt BA (1984) Sensitivity of rat inferior olivary neurons to 3-acetylpyridine. Dev Brain Res 12:285-291.

Azizi SA, Woodward DJ (1987) Inferior olivary nuclear complex of the rat: morphology and comments on the principles of organization within the olivocerebellar system. J Comp Neurol 263:467-484.

Balaban CD (1985) Central neurotoxic effects of intraperitoneally administered 3-acetylpyridine, harmaline and niacinamide in SpragueDawley and Long-Evans rats: a critical review of central 3acetylpyridine neurotoxicity. Brain Res. 356:21-42. 
Batini C, Buisseret-Delmas C, Conrath-Verrier M (1981) Harmalineinduced tremor. Exp Brain Res 42:371-382.

Battista AF, Nakatani S, Goldstein M, Anagnoste B (1990) Effect of harmaline in monkeys with CNS lesions. Exp Neurol 28:513-524.

Baude A, Nusser Z, Roberts JD, Mulvihill E, McIlhinney RA, Somogyi $\mathrm{P}$ (1993) The metabotropic glutamate receptor (mGluR1 alpha) is concentrated at perisynaptic membrane of neuronal subpopulations as detected by immunogold reaction. Neuron 11:771-787.

Benedetti F, Montarolo PG, Rabacchi S (1984) Inferior olive lesion induces long-lasting functional modification in the Purkinje cells. Exp Brain Res 55:368-371.

Bertolino M, Llinás R (1992) The central role of voltage-activated and receptor-operated calcium channels in neuronal cells. Annu Rev Pharmacol Toxicol 32:399-421.

Blackwood W, Corsellis JAN (1976) Greenfield's neuropathology. London: Arnold.

Bradley P, Berry M (1976) Quantitative effects of climbing fiber deafferentation on the adult Purkinje cell dendritic tree. Brain Res 112:133-140.

Brodal A (1954) Afferent cerebellar connexions. In: Aspects of cerebellar anatomy (Jansen J, Brodal A, eds), pp 82-188. Oslo: Johan Grundt Tanum Forlag.

Brodal A, Kawamura K (1980) Olivocerebellar projection: a review. Adv Anat Embryol Cell Biol. 64:1-140.

Brorson JR, Manzolillo PA, Miller RJ (1994) $\mathrm{Ca}^{2+}$ entry via AMPA/KA receptors and excitotoxicity in cultured cerebellar Purkinje cells. J Neurosci 14:187-197.

Buisseret-Delmas C, Angaut P (1993) The cerebellar olivocorticonuclear connections in the rat. Prog Neurobiol 40:63-87.

Choi DW (1987) Ionic dependence of glutamate neurotoxicity. J Neurosci 7:369-379.

Choi DW (1988) Glutamate neurotoxicity and diseases of the nervous system. Neuron 1:623-634.

Colin F, Manil J, Desclin JC (1980) The olivocerebellar system. I. Delayed and slow inhibitory effects: an overlooked salient feature of cerebellar climbing fibers. Brain Res 187:3-27.

Crepel F, Audinat E (1991) Excitatory amino acid receptors of cerebellar Purkinje cells: development and plasticity. Prog Biophys Mol Biol 55:31-46.

Crepel F, Dhanjal SS, Sears TA (1982) Effect of glutamate, aspartate and related derivatives on cerebellar Purkinje cell dendrites in the rat: an in vitro study. J Physiol (Lond) 329:297-317.

De Montigny C, Lamarre Y (1973) Rhythmic activity induced by harmaline in the olivo-cerebello-bulbar system of the cat. Brain Res 53:81-95.

De Montigny C, Lamarre Y (1974) Activity in the olivo-cerebello-bulbar system of the cat during ibogaline- and oxotremorine-induced tremor. Brain Res 82:369-373.

De Montigny C, Lamarre Y (1975) Effects produced by local applications of harmaline in the inferior olive. Can J Physiol Pharmacol 53:845-849.

de Zeeuw CI, Lang EJ, Sugihara I, Ruigrok TJH, Eisenman LM, Mugnaini E, Llinás R (1996) Morphological correlates of bilateral synchrony in the rat cerebellar cortex. J Neurosci 16:3412-3426.

Desclin JC (1974) Histological evidence supporting the inferior olive as the major source of cerebellar climbing fibers in the rat. Brain Res 77:365-384.

Desclin JC, Escubi J (1974) Effects of 3-acetylpyridine on the CNS of the rat, as demonstrated by silver methods. Brain Res 77:349-364.

Dhahir HI (1971) A comparative study on the toxicity of ibogaine and serotonin. PhD thesis, Indiana University 71:1-151.

Eccles JC, Llinás R, Sasaki K (1966a) The excitatory synaptic action of climbing fibers on the Purkinje cells of the cerebellum. J Physiol (Lond) 182:268-296.

Eccles JC, Llinás R, Sasaki K (1966b) Intracellularly recorded responses of the cerebellar Purkinje cells. Exp Brain Res 1:161-183.

Eccles JC, Ito M, Szentágothai J (1967) The cerebellum as a neuronal machine. Berlin: Springer.

Garthwaite G, Hajos F, Garthwaite J (1986) Ionic requirements for neurotoxic effects of excitatory amino acid analogues in rat cerebellar slices. Neuroscience 18:437-447.

Glick SD, Rossman K, Rao NC, Maisonneuve IM, Carlson JN (1992) Effects of ibogaine on acute signs of morphine withdrawal in rats: independence from tremor. Neuropharmacology 31:497-500.

Groenewegen HJ, Voogd J (1977) The parasagittal zonation within the olivocerebellar projection. I. climbing fiber distribution in the vermis of cat cerebellum. J Comp Neurol 174:417-488.

Jonas P, Racca C, Sakmann B, Seeburg PH, Monyer H (1994) Differences in $\mathrm{Ca}^{2+}$ permeability of AMPA-type glutamate receptor channels in neocortical neurons caused by differential GluR-B subunit expression. Neuron 12:1281-1289.

Konnerth A, Llano I, Armstrong CM (1990) Synaptic currents in cerebellar Purkinje cells. Proc Natl Acad Sci USA 87:2662-2665.

Kostyuk PG (1990) Calcium channels in cellular membranes. J Mol Neurosci 2:123-141.

Lamarre Y, Mercier LA (1971) Neurophysiological studies of harmalineinduced tremor in the cat. Can J Physiol Pharmacol 49:1049-1058.

Lamarre Y, Weiss M (1973) Harmaline-induced rhythmic activity of alpha and gamma motoneurons in the cat. Brain Res 63:430-434.

Lamarre Y, De Montigny C, Dumont M, Weiss M (1971) Harmalineinduced rhythmic activity of cerebellar and lower brain stem neurons. Brain Res 32:246-250.

Llano I, Dreessen J, Kano M, Konnerth A (1991) Intradendritic release of calcium induced by glutamate in cerebellar Purkinje cells. Neuron 7:577-583.

Llinás R, Nicholson C (1971) Electrophysiological properties of dendrites and somata in alligator Purkinje cells. J Neurophysiol 34:532-551.

Llinás R, Sasaki K (1989) The functional organization of the olivocerebellar system as examined by multiple Purkinje cell recordings. Eur J Neurosci 1:587-602.

Llinás R, Sugimori M (1980) Electrophysiological properties of in vitro Purkinje cell dendrites in mammalian cerebellar slices. J Physiol (Lond) 305:197-213.

Llinás R, Volkind RA (1973) The olivo-cerebellar system: functional properties as revealed by harmaline-induced tremor. Exp Brain Res 18:69-87.

Llinás R, Yarom Y (1986) Oscillatory properties of guinea-pig inferior olivary neurones and their pharmacological modulation: an in vitro study. J Physiol (Lond) 376:163-182.

Llinás R, Bloedel JR, Hillman DE (1969) Functional characterization of neuronal circuitry of frog cerebellar cortex. J Neurophysiol 32:847-870.

Llinás R, Baker R, Sotelo C (1974) Electrotonic coupling between neurons in cat inferior olive. J Neurophysiol 37:560-571.

Llinás R, Walton K, Hillman DE, Sotelo C (1975) Inferior olive: Its role in motor learning. Science 190:1230-1231.

Lotsof HS (1985) Rapid method for interrupting the narcotic addiction syndrome. US patent 4,499,096.

Lotsof HS (1986) Rapid method for interrupting the cocaine and amphetamine abuse syndrome. US patent $4,587,243$.

Lotsof HS (1995) Ibogaine in the treatment of chemical dependency disorders: clinical perspectives. Multidisciplinary Assoc Psychedelic Studies 5:16-27.

Martin LJ, Blackstone CD, Huganir RL, Price DL (1992) Cellular localization of a metabotropic glutamate receptor in rat brain. Neuron 9:259-270.

Masu M, Tanabe Y, Tsuchida K, Shigemoto R, Nakanishi S (1991) Sequence and expression of a metabotropic glutamate receptor. Nature 349:760-765.

Milner TE, Cadoret G, Lessard L, Smith AM (1995) EMG analysis of harmaline-induced tremor in normal and three strains of mutant mice with Purkinje cell degeneration and the role of the inferior olive. J Neurophysiol 73:2568-2577.

Miyakawa H, Ross WN, Jaffe D, Callaway JC, Lasser-Ross N, Lisman JE, Johnston D (1992) Synaptically activated increases in $\mathrm{Ca}^{2+}$ concentration in hippocampal CA1 pyramidal cells are primarily due to voltage-gated $\mathrm{Ca}^{2+}$ channels. Neuron 9:1163-1173.

Molinari HH, Maisonneuve IM, Glick SD (1996) Ibogaine neurotoxicity: a re-evaluation. Brain Res 737:255-262.

O'Hearn E, Molliver ME (1993) Degeneration of Purkinje cells in parasagittal zones of the cerebellar vermis after treatment with ibogaine or harmaline. Neuroscience 55:303-310.

O’Hearn E, Molliver ME (1994) Ibogaine treatment induces c-fos protein in widespread areas of the forebrain, independent of activation of the inferior olivary nucleus. Soc Neurosci Abstr 20:272.

O'Hearn E, Long DB, Molliver ME (1993) Ibogaine induces glial activation in parasagittal zones of the cerebellum. NeuroReport 4:299-302.

O'Hearn E, Zhang P, Molliver ME (1995) Excitotoxic insult due to ibogaine leads to delayed induction of neuronal NOS in Purkinje cells. NeuroReport 6:1611-1616. 
Olney JW (1978) Neurotoxicity of excitatory amino acids. In: Kainic acid as a tool in neurobiology (McGeer EG, Olney JW, McGeer PO, eds), pp 95-171. New York: Raven.

Olney JW, Ho OL, Rhee V (1971) Cytotoxic effects of acidic and sulphur containing amino acids on the infant mouse CNS. Exp Brain Res 14:61-76.

Orrenius S, Ankarcrona M, Nicotera P (1996) Mechanisms of calciumrelated cell death. Adv Neurol 71:137-151.

Oscarsson O (1976) Spatial distribution of climbing and mossy fiber inputs into the cerebellar cortex. Brain Res [Suppl] 1:36-42.

Palay SL, Chan-Palay V (1974) Cerebellar cortex, cytology and organization. Berlin: Springer.

Perkel DJ, Hestrin S, Sah P, Nicoll RA (1990) Excitatory synaptic currents in Purkinje cells. Proc R Soc Lond [Biol] 241:116-121.

Popik P, Layer RT, Skolnick P (1995) 100 years of ibogaine: neurochemical and pharmacological actions of a putative anti-addictive drug. Pharmacol Rev 47:235-253.

Rosenmund C, Legendre P, Westbrook GL (1992) Expression of NMDA channels on cerebellar Purkinje cells acutely dissociated from newborn rats. J Neurophysiol 68:1901-1905.

Ross CA, Meldolesi J, Milner TA, Satoh T, Supattapone S, Snyder SH (1989) Inositol 1,4,5-trisphosphate receptor localized to endoplasmic reticulum in cerebellar Purkinje neurons. Nature 339:468-470.

Rossi F, Wiklund L, Van der Want JJL, Strata P (1991) Reinnervation of cerebellar Purkinje cells by climbing fibers surviving a subtotal lesion of the inferior olive in the adult rat. I. Development of new collateral branches and terminal plexuses. J Comp Neurol 308:513-535.

Sasaki K, Bower JM, Llinás R (1989) Multiple Purkinje cell recording in rodent cerebellar cortex. Eur J Neurosci 1:572-586.

Satoh T, Ross CA, Villa A, Supattapone S, Pozzan T, Snyder SH, Meldolesi J (1990) The inositol 1,4,5,-trisphosphate receptor in cerebellar Purkinje cells: quantitative immunogold labeling reveals concentration in an ER subcompartment. J Cell Biol 111:615-624.

Schneider JA, Sigg EB (1956) Neuropharmacological studies on ibo- gaine, an indole alkaloid with central-stimulant properties. Ann NY Acad Sci 66:765-776.

Sheppard SG (1994) A preliminary investigation of ibogaine: case reports and recommendations for further study. J Subst Abuse Treat 11:379-385.

Siman R, Noszek JC (1988) Excitatory amino acids activate calpain I and induce structural protein breakdown in vivo. Neuron 1:279-287.

Simantov R, Snyder SH, Oster-Granite ML (1976) Harmaline-induced tremor in the rat: abolition by 3-acetylpyridine destruction of cerebellar climbing fibers. Brain Res 114:144-151.

Singbartl G, Zetler G, Schlosser L (1973) Structure-activity relationships of intracerebrally injected tremorigenic indole alkaloids. Neuropharmacology 12:239-244.

Sorimachi M (1993) Calcium permeability of non- $N$-methyl-D-aspartate receptor channels in immature cerebellar Purkinje cells: studies using fura-2 microfluorometry. J Neurochem 60:1236-1243.

Sotelo C, Llinás R, Baker R (1974) Structural study of inferior olivary nucleus of the cat: morphological correlates of electrotonic coupling. J Neurophysiol 37:541-559.

Sotelo C, Hillman DE, Zamora AJ, Llinás R (1975) Climbing fiber deafferentation: its action on Purkinje cell dendritic spines. Brain Res 98:574-581.

Szentágothai J, Rajkovits K (1959) Uber den ursprung der kletterfasern des kleinhirns. Z Anat Entwickl-Gesch 121:130-141.

Zetler G, Singbartl G, Schlosser L (1972) Cerebral pharmacokinetics of tremor-producing harmala and iboga alkaloids. Pharmacology 7:237-248.

Zetler G, Back G, Iven H (1974) Pharmacokinetics in the rat of the hallucinogenic alkaloids harmine and harmaline. Naunyn Schmiedebergs Arch Pharmacol 285:273-292.

Zhang N, Walberg F, Laake JH, Meldrum BS, Ottersen OP (1990) Aspartate-like and glutamate-like immunoreactivities in the inferior olive and climbing fiber system: a light microscopic and semiquantitative electron microscopic study in rat and baboon (Papio anubis). Neuroscience 38:61-80. 